Monika Walec ${ }^{1}$, https://orcid.org/0000-0001-6115-639X

Weronika Michon'1, https:/ / orcid.org/0000-0002-7965-5354

Natalia Surma ${ }^{1}$, https:/ / orcid.org/0000-0003-4669-7686

${ }^{1}$ Student Research Club at the Department of Family Medicine and Community Nursing

Faculty of Health Sciences, Medical University of Lublin

Marcin Rząca, MD, PhD, https:/ / orcid.org/0000-0003-3287-2025

Department of Oncology, Chair of Oncology and Environmental Health

Faculty of Health Sciences, Medical University of Lublin

Grzegorz Józef Nowicki², MD, PhD, https:// orcid.org/0000-0002-0503-8847

Associate Professor Barbara Ślusarska², MD, PhD, https:/ / orcid.org/0000-0003-0101-9216

2 Department of Family Medicine and Community Nursing

Faculty of Health Sciences, Medical University of Lublin

\title{
Impact of Coronavirus Outbreak Events, Perceptions of Sense of Safety and Distance Learning Among College Students During the COVID-19 Pandemic
}

\author{
Wpływ zdarzeń związanych z epidemią koronawirusa, postrzeganie \\ poczucia bezpieczeństwa i kształcenia zdalnego wśród studentów \\ uczelni wyższych podczas pandemii COVID-191 \\ https:// doi.org/10.34766/fetr.v47i3.843
}

\begin{abstract}
A pandemic affects numerous areas of social life substantially. Significant changes have occurred in the area of education, including higher education. In the spring semester of the academic year 2019/2020, universities in Poland, within a matter of weeks, switched from full-time teaching to distance learning. This undoubtedly caused a degree of uncertainty among students regarding the development of events and the need to act in changing circumstances. It also involved a revision of communication patterns and interaction on many levels. The purpose of the present study was to determine the impact of the coronavirus outbreak on perceptions of security and higher education during the COVID-19 pandemic from the perspective of college students participating from universities across Poland. The study was conducted in May and June 2020 among 371 students in Poland by means of computer-assisted web interviewing (CAWI). Two standardized tools were used: the Polish version of the Impact Event Scale-Revised (IES-R) and the Security Experience Questionnaire (SEQ), as well as a proprietary survey questionnaire. The survey was posted on Google.com and also shared with the respondents online via Facebook. The students demonstrated significant effort in ridding themselves of trauma-related thoughts, emotions, or conversations. A sense of security was noted which, however, decreased significantly where PTSD scores increased. The male respondents had a significantly higher sense of security than did the female respondents. There was no evidence of influence based on field of study, year of study, or type of education upon the severity of traumatic stress or the experiencing of security. In terms of the impact of the epidemic on aspects of higher education, respondents showed concern for the quality of interpersonal relationships and the financial situations of their families. The traumatic stress severity index was
\end{abstract}

\footnotetext{
${ }^{1}$ Polska wersja: https:/ / stowarzyszeniefidesetratio.pl/Presentations0/2021-3-Wale.pdf
} 
found to be significantly higher in terms of content and technical aspects of education. The students' state of mind seemed to have no relationship to the gender of the respondent or the type of education. The impact of events related to the outbreak of the Sars-Cov-2 virus can be observed in a disturbance of the sense of security among participants of varying majors and years of study in Poland. Students' fears were associated with a change in the realities of student life, in both the educational and the social spheres.

Keywords: COVID-19, distance learning, higher education, PTSD, stress, sense of security

Abstrakt: Pandemia wpływa istotnie na szereg obszarów życia społecznego. Znaczące zmiany nastąpiły $\mathrm{w}$ obszarze szkolnictwa $\mathrm{w}$ tym także szkolnictwa wyższego. $\mathrm{W}$ semestrze letnim roku akademickiego 2019/2020 uczelnie w Polsce, w przeciągu kilku tygodni, przeszły z nauczania stacjonarnego na nauczanie zdalne, co niewątpliwie zrodziło wśród studentów określony poziom niepewności, co do rozwoju wydarzeń i konieczność działania w zmieniających się okolicznościach oraz wiązało się ze zmienionym wzorcem komunikacji i interakcji na wielu płaszczyznach funkcjonowania. Celem niniejszej pracy było określenie wpływu zdarzeń związanych z epidemią koronawirusa, na postrzeganie poczucia bezpieczeństwa i kształcenia $\mathrm{w}$ zakresie szkolnictwa wyższego podczas pandemii COVID-19 z perspektywy uczestników studiów uczelni wyższych z całej Polski. Badania były przeprowadzone w okresie maja i czerwca 2020 roku wśród 371 studentów w Polsce, metodą computer-assisted web interviewing (CAWI). Wykorzystano w tym celu dwa narzędzia standaryzowane tj. polską wersję Zrewidowanej Skali Wpływu Zdarzeń i Kwestionariusz Doświadczania Bezpieczeństwa oraz autorski kwestionariusz ankiety. Ankietę zamieszczono na portalu Google.com, które udostępniono badanym internetowo, za pomocą portalu Facebook. Studenci wykazali znaczny wysiłek pozbycia się myśli, emocji czy rozmów związanych z traumą. Zaobserwowano stan poczucia bezpieczeństwa, który jednak istotnie zmniejszał się, wraz ze wzrostem wskaźnika PTSD. Mężczyźni posiadają istotnie większe poczucie bezpieczeństwa niż kobiety. Nie wykazano wpływu kierunku, roku studiów lub rodzaju kształcenia na nasilenie stresu traumatycznego i doświadczania bezpieczeństwa. W kontekście wpływu epidemii na aspekty związane z kształceniem na uczelni wyższej, badani wykazali obawy o jakość relacji międzyludzkich i sytuację materialną rodziny. Wskaźnik nasilenia stresu traumatycznego okazał się istotnie wyższy w sprawie merytorycznego oraz technicznego przebiegu kształcenia. Nastroje studentów wydają się nie mieć związku z płcią ankietowanego czy też rodzajem kształcenia. Wpływ zdarzeń związanych z epidemią wirusa SARS-CoV-2 daje się zaobserwować w zaburzeniu poczucia bezpieczeństwa wśród uczestników różnych kierunków i lat studiów w Polsce. Obawy studentów wiążą się ze zmianą realiów życia studenckiego $\mathrm{w}$ wymiarze dydaktycznym jak i społecznym.

Słowa kluczowe: COVID-19, kształcenie zdalne, studia wyższe, PTSD, stres, poczucia bezpieczeństwa

\section{Introduction}

The World Health Organization (WHO) announcement in March 2020 of the (Corona Virus Disease 2019) pandemic, of a highly infectious disease with a long incubation period, caused by the Severe Acute Respiratory Coronavirus 2 (SARS-Cov-2) virus (Huang, Wang, $\mathrm{Li}$, et al., 2020; WHO, 2020), has disrupted the order and routine of life for societies around the world. The first case of coronavirus infection in Poland was reported on March 4, 2020 (in western Poland). Since then, the number of those infected has steadily increased, resulting in the declaration of a state of epidemic by the Minister of Health on March 20, 2020. In response to the coronavirus outbreak, government authorities adopted many drastic measures to protect the population, including closing the country's borders, a mandatory 14day quarantine for people returning from abroad, working from home, the suspension of onsite activities at schools and universities, limiting retail store occupancy, limiting the number 
of worshipers in churches, the obligatory wearing of masks covering nose and mouth, and the closure of some services (e.g. hairdressers, beauticians, etc.) and venues related to culture (e.g. cinemas, theaters, exhibitions, etc.). The rapid spread of SARS-Cov-2 and the increase in COVID-19 infections prompted a need to change the existing model of activities and habits characterizing human interaction. Essential aspects of life previously accomplished through face-to-face contact had to be transformed to a remote-access mode. This had a particularly powerful impact on work environments and on education. It is estimated that due to the epidemiological crisis, more than 1.5 billion students worldwide have experienced changes in the learning process. Higher education has undergone transformation for approximately $90 \%$ of students globally (Bozkurt \& Sharma, 2020).

In the spring semester of the 2019/2020 academic year, universities in Poland transitioned from on-site teaching to remote education within a matter of weeks. Remote education, i.e., the use of information and communication technology, had become a necessity. The SARS-CoV-2 virus pandemic and these aggressive changes in education have created a difficult and even crisis situation in student life with its specificity, dynamics, and social context. A crisis is a breakdown in life resulting from an event that has become an obstacle to realizing life goals, and consequently provokes strong emotions. A crisis situation is a state of disorganization in which a person feels anxiety, shock, and difficulty associated with experiencing a particular situation (James \& Gilliland, 2006).

The differences in education being brought into existence by universities may have significantly affected students' perceptions of the educational process, generating various types of obstacles in the process of obtaining knowledge. The limited opportunities for practical training, along with technical problems in conveying theoretical content, may have translated into a reduced sense of security and of student values. Even though online access solutions are not new to the academic and scientific community, the epidemiological crisis that hasarisen and the increased need to use remote tools in the short term may have caused problems in the functioning of the system (Mian \& Khan, 2020; Guadix, Winston, Chae, et al., 2020). With regard to the characteristics of courses of study in individual majors, the greatest disturbances can be expected in medical and technical faculties. Their highly practical educational profile is linked to greater losses associated with reduced access to assignments. The risk of SARS-CoV-2 virus transmission has prevented students from interacting with patients in teaching hospitals, which reduces their opportunity to gain valuable experience and acquire knowledge necessary to complete their education. Lack of access to technical labs as well as the restructured system of conducting examinations are other considerations that might have negatively affected students' frame of mind (Mian \& Khan, 2020) and their assessments of the impact events associated with the coronavirus outbreak have had on the university's stated educational goals. 
The COVID-19 pandemic not only affects physical health but can also lead to mental health problems such as sleep disorders, depression, and post-traumatic stress symptoms (Pfefferbaum \& North, 2020; Holmes, O'Connor, Hugh, et al., 2020). A major infectious disease pandemic can have widespread and pervasive detrimental effects on individuals' mental health (Terhakopian \& Benedek, 2007). For example, a sudden disease outbreak that is associated with a high rate of infection and rapid transmission creates fear, anxiety, and distress in the community (Bonanno, Ho, Chan, et al., 2008; Sim, 2016). The prolonged stress and anxiety caused by a pandemic can further trigger symptoms of depression (Keita, 2017). The constant exposure to danger, illness, death, catastrophic situations, stigma, and discrimination during a pandemic can cause an acute stress response and even induce posttraumatic stress reactions (Jakovljevic, Bjedov, Jaksic, et al., 2020). Post-traumatic stress disorder (PTSD) is a common, severe, and complex mental disorder that occurs after exposure to traumatic events. It is characterized by the intrusion and re-experiencing of the trauma through dissociative reactionssuch as flashbacks, attempts to avoid thoughts, feelings, places, or people associated with the trauma, persistent negative perceptions and mood, and agitation in the form of anxiety, sleep difficulties, or irritability (Shalev, Liberzon, Marmar, 2017).

The incidence of post-traumatic stress disorder following infectious disease pandemics of the 21st century, including COVID-19, is mixed, according to a meta-analysis made from 88 studies and systematic reviews. Post-pandemic PTSD in the overall population was $22.6 \%$ (95\% confidence interval [CI]: 19.9-25.4\%). The highest prevalence of PTSD was observed in healthcare workers (26.9\%; 95\% CI: 20.3-33.6\%), followed by infected individuals (23.8\%: 16.6-31.0\%) and the general public (19.3\%: 15.3-23.2\%) (Yuan, Gong, Liu, et al., 2021). Among the numerous factors associated with the pandemic, some have been linked to an increased risk of PTSD. Quarantine or experience of social isolation due to the pandemic (Sprang \& Silman, 2013; González Ramírez, Martínez Arriaga, Hernández-Gonzalez, et al., 2020; Rossi, Socci, Talevi, et al., 2020; Shi, Lu, Que, et al., 2020) were a major risk factor for post-pandemic PTSD, along with poor social life (Lau, 2005) and economic losses (Sun, Goldberg, Lin, et al., 2020; Wei, Meng, Ni, 2020). In addition, having a high-risk or perceived high-risk of infection was also linked to a higher probability of post-pandemic PTSD associated with suspected or confirmed infection (Xu, Zheng, Wang, et al., 2011). A crosssectional study of 1,912 university students in China (conducted in March and April 2020) assessing psychiatric symptoms (depression, anxiety, and traumatic stress) during stateenforced quarantine revealed symptoms ranging from mild to higher, based on clinical cutoff points, as follows: $67.05 \%$ of students reported traumatic stress symptoms, $46.55 \%$ had symptoms of depression, and $34.73 \%$ reported anxiety symptoms. In addition, $19.56 \%$ entertained suicidal thoughts to some extent (Sun, Goldberg, Lin, et al., 2020). 
Considering the above arguments, it seems relevant to learn the level of posttraumatic stress, the sense of security, and the perception of distance learning in the new conditions of higher education. For this reason we undertook the evaluation of these factors among students.

\section{Material and method}

\subsection{Purpose of the study}

The present study focuses on determining the impact of coronavirus outbreak events, perceptions of feelings of safety, and higher education during the COVID-19 pandemic from the perspective of university study respondents from across Poland. The authors have paid particular attention to the stressful effects of the social lockdown that took place, and to the phenomenon of social distancing. This study aims to learn the state of mind prevailing among students, differentiating between majors and years of higher education. It indicates changes in perception of daily life and sense of security in the educational process.

\subsection{Research Project}

This is a cross-sectional survey that was conducted between May 9 and June 9, 2020, among 371 students in Poland. Since the government had introduced restrictions on face-toface meetings as well implementing home isolation, the survey was carried out by means of computer-assisted web interviewing (CAWI). The survey was conducted among students using the ten most popular Facebook fan pages targeted at students in Poland. The fan page administrators were asked to post a link to the survey on their message boards twice over the course of the survey, that is, on the first and seventh days of the survey. The posted link redirected the study participant to a poll on the "google surveys" portal. Participants could only complete the survey once. Research stages within the project: 1 . Creation of an electronic version of the survey questionnaire on google.com; 2 . Requesting a link to the questionnaire through Facebook fan pages directed to students; 3. Statistical processing of the obtained research material and preparation for publication; and 4. Preparation of an educational module for students for forming competencies in coping with traumatic experiences working in high risk coronavirus conditions in academic education.

\subsection{Ethical approval}

Ethical approval was granted by the Bioethics Committee of the Medical University of Lublin (Decision number: KE-0254/73/2020). The study was conducted in accordance with the ethical principles contained in Recommendations from the Association of Internet Researchers. (Markham, Buchanan, 2012). Participation in the study was voluntary and anonymous. All study participants gave their informed consent to participate in the study 
electronically. The informed consent page included an explanation of the purpose and methodology of the study. It contained the option to choose to take part by selecting the "Yes" or to decline by selecting "No." Only respondents who selected "Yes" were taken to the questionnaire page. The respondent could opt out of the study at any time by closing the web page with the survey questionnaire.

\subsection{Study participants}

To be eligible to participate in the study, respondents had to meet the following inclusion and exclusion criteria. Inclusion criteria: 1 . Being a student pursuing distance education during the coronavirus outbreak defined as the period beginning March 20, 2020; 2. Participation in educational activities at the university before the announcement of the coronavirus outbreak defined as January and February 2020; and 3. Providing informed consent to participate in the study by answering "Yes." Exclusion criteria were: 1. Being on sick leave, maternity leave, parental leave, or childcare leave before the declaration of the outbreak in Poland (January and February 2020); 2. Being on sick leave, maternity leave, parental leave, or childcare leave after the declaration of the outbreak in Poland; 3 . Being on dean's leave during the course of the study; or 4. Not giving informed consent to participate in the study.

\subsection{Research Tools}

To achieve the objectives of the study, a structured questionnaire was developed consisting of two standard tools and a proprietary tool. The tools used in this study were questionnaires assessing:

\subsubsection{Symptoms of stress associated with traumatic stress}

To assess traumatic stress, including trauma-related distressing memories and lasting negative emotions resulting from the pandemic, we used the Polish version of the Impact Event Scale-Revised (IES-R) by Weiss and Marmar (1997) in the Polish adaptation of Juczyński and Ogińska-Bulik (2009). The scale consists of 22 statements describing symptoms of perceived stress during the last seven days concerning the experienced traumatic event. The assessment is made on a five-point Likert scale (from 0-4). It is used to determine the current subjective sense of discomfort associated with the specific events that had occurred. It captures the three dimensions of PTSD: Intrusion (expressing recurrent images, dreams, thoughts, or perceptual impressions associated with the trauma), Hyperarousal (characterized by increased alertness, anxiety, impatience, and difficulty focusing attention), and Avoidance (manifested by an effort to rid oneself of thoughts, emotions, or conversations associated with the trauma). In analyzing the results, we adopted the more restrictive approach justified by the current criteria for diagnosing PTSD, that a diagnosis of 
PTSD can be suspected only in those individuals whose result is higher than the cutoff point $(>1.5)$ in their total score and in each of the three dimensions. Internal consistency, as assessed by Cronbach's alpha, was .92 for the scale as a whole, and for Intrusion, Hyperarousal, and Avoidance, respectively: .89, .85, and .78 (Juczynski, Oginska-Bulik, 2009). In our study we used a modification of the statements included in the scale such that they indicated the current situation associated with the coronavirus epidemic. The thirteen statements of the scale specified the coronavirus epidemic as the item that should be assessed in each statement. In the study group, the internal consistency for the entire scale was .89 , while for the individual subscales, Intrusion was .86, Hyperarousal was .80, and Avoidance was .74.

\subsubsection{Assessment of the level of experience of security during the coronavirus pandemic}

The Security Experience Questionnaire (SEQ) by Klamut (2019) was used to assess the level of security experienced. The scale uses a two-factor model with two subscales: Sense of Security and Reflection on Security. The Sense of Security scale examines the level of experiencing security associated with the belief that one's basic needs are currently being met and that one has satisfactory living conditions and opportunities for activity. The scale of Reflection on Security examines the degree of taking into account issues concerning the safety of oneself, of loved ones, the nation, and the world in assessing life situations and social conditions. The scale consists of nine statements (five for the Sense of Security subscale and four for the Reflection on Security subscale). The respondent is asked to respond on a five-point Likert scale as to how the statement relates to his/her current situation (from 1 strongly disagree to 5 - strongly agree). Reliability as measured by Cronbach's alpha coefficient for the Feeling Safe subscale was .85 and for the Reflection on Security subscale was .68 (Klamut, 2019). In our study, Cronbach's alpha coefficient for the Sense of Security subscale was .84 and for the Reflection on Security subscale was .64.

\subsubsection{Sociodemographic variables}

In successive questions, respondents were asked to provide several sociodemographic variables. They were asked about: gender, age, place of residence, those with whom the respondent lives, and questions about the type of academic institution, course, and year of study.

\subsection{Methods of statistical analysis}

The results of the study were presented in relation to qualitative data using count and percentage and quantitative data using mean, standard deviation, median, and minimum and maximum value. To verify the presence of statistically significant relationships, analysis 
was performed using Pearson's non-parametric Chi2 test for qualitative data. The distribution of quantitative data was examined using the Shapiro-Wilk Test. Upon determination of a non-normal distribution, the Mann-Whitney $U$ Test was employed to compare two groups, and the Kruskal Wallis Test was used to compare three groups. In cases of data distribution conforming to the norm, the Student's T-test was applied to compare two groups and for more than two groups, the Anova analysis of variance was used. The Spearman's R correlation coefficient was also determined. A value of $p<.05$ was considered as statistically significant. The analysis was conducted using the StatSoft Statistica 13.0 PL statistical package.

\section{Results}

\subsection{Characteristics of the group being researched}

Table 1 shows the sociodemographic characteristics of the study group. A total of 371 students from all over the country participated in the study (Figure 1). The mean age was $22.3 \pm 4.5$ years. Most of the respondents lived in cities $(61.2 \% ; n=227)$ and with family $(74.9 \% ; \mathrm{n}=278)$. The vast majority of respondents were undergraduate students $(79.8 \%$; $\mathrm{n}=296)$, first and third-year students $(42.9 \%, \mathrm{n}=159$ and $27.5 \%, \mathrm{n}=102$, respectively). More than half of the respondents represented medical education majors $(53.1 \%, \mathrm{n}=197)$.

Table 1. Sociodemographic characteristics of the group of students studied $(n=371)$.

\begin{tabular}{|c|c|c|}
\hline Variables & Variable categories & $\mathrm{n}(\%)$ \\
\hline \multirow{6}{*}{ Age [years] } & \multicolumn{2}{|c|}{$\mathrm{M}=22.3(\mathrm{SD}=4.5), \mathrm{Me}=21, \mathrm{Q} 1=18, \mathrm{Q} 3=59$} \\
\hline & $<21$ & 108 (29.1) \\
\hline & $21-23$ & $216(58.2)$ \\
\hline & $24-25$ & $19(5.1)$ \\
\hline & $26-30$ & $11(3.0)$ \\
\hline & $>30$ & 17 (4.6) \\
\hline \multirow{2}{*}{ Gender } & Female & 299 (80.6) \\
\hline & Male & 72 (19.4) \\
\hline \multirow{2}{*}{$\begin{array}{l}\text { Place of } \\
\text { residence }\end{array}$} & City & $227(61.2)$ \\
\hline & Village & 144 (38.8) \\
\hline \multirow{4}{*}{ Lives with } & Family & $278(74.9)$ \\
\hline & Partner & 42 (11.3) \\
\hline & Roommate & $36(9.7)$ \\
\hline & Alone & $15(4.0)$ \\
\hline
\end{tabular}




\begin{tabular}{|c|c|c|}
\hline Variables & Variable categories & $\mathrm{n}(\%)$ \\
\hline \multirow{3}{*}{ Stage of education } & Bachelor & $296(79.8)$ \\
\hline & Master & $46(12.4)$ \\
\hline & Uniform Master & $29(7.8)$ \\
\hline \multirow{5}{*}{ Year of study } & I & $159(42.9)$ \\
\hline & II & $89(24)$ \\
\hline & III & $102(27.5)$ \\
\hline & IV & $13(3.5)$ \\
\hline & $\mathrm{V}$ & $8(2.2)$ \\
\hline \multirow{9}{*}{ Major } & Medical & $197(53.1)$ \\
\hline & Humanities & $41(11.1)$ \\
\hline & Science & $26(7.0)$ \\
\hline & Natural Science & $13(3.5)$ \\
\hline & Technical & $32(8.6)$ \\
\hline & Social & $37(10.0)$ \\
\hline & Arts & $10(2.7)$ \\
\hline & Economics & $9(2.4)$ \\
\hline & Other (national security, economic, sport, political) & $6(1.6)$ \\
\hline
\end{tabular}

Abbreviations: M - mean; SD - standard deviation; Me - median; Q1 - upper quartile; Q2 - lower quartile.

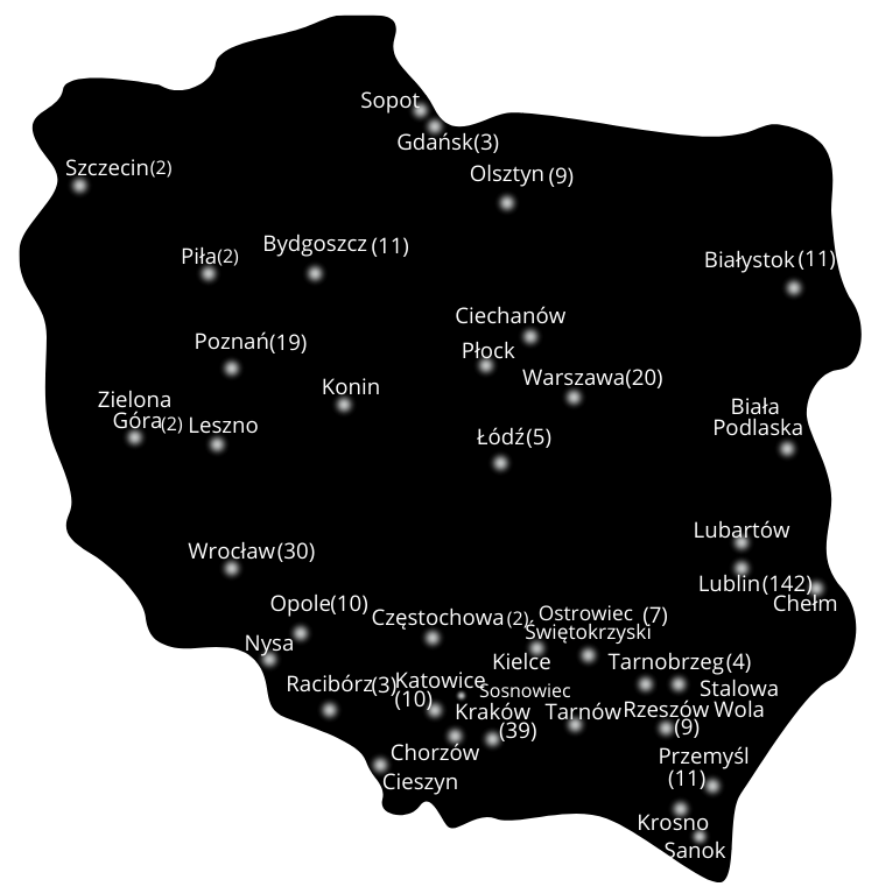

Figure 1. Map of Poland with distribution of respondents' participation in the study 


\subsection{Traumatic stress symptoms among students according to the IES-R and}

\section{experience of security according to the SEQ and their relationship to selected variables}

Table 2 shows the mean overall score for traumatic stress and its three dimensions and the experience of security scores. The mean total score of the IES-R scale for the study group was $1.40 \pm .62$. Among the subscales of traumatic stress, the highest score was obtained in the Avoidance dimension $1.79 \pm .82$, followed by the Hyperarousal dimension $1.45 \pm .73$ and Intrusion dimension $1.02 \pm .72$. Since the total score and the Intrusion and Avoidance dimensions are lower than 1.5 among those studied, traumatic stress symptoms could not be diagnosed. In the Avoidance dimension, the score is higher than 1.5, which indicates a significant effort to get rid of thoughts, emotions, or conversations related to the trauma. Security Experience Scale (SEQ) scores in the mid-high range indicate a state of feeling safe, both in the Feeling of Security $(3.68 \pm .68)$ and Reflecting on Security $(4.08 \pm .57)$ subscales.

It was observed that the higher a student's PTSD score on the IES-R scale, the lower his/her Sense of Security $(p<.0001)$; and as the IES-R total score increased, Reflection on Security also increased $(p<.001)$. The Intrusion and Agitation subscales significantly increased with a decreasing Sense of Security $(p<.0001)$. The greater the PTSD in the Intrusion and Avoidance subscales, the considerably greater the Reflection of Security of the subjects $(p<.0001)$.

Table 2. Traumatic stress scores among students according to the IES-R and experience of security according to the SEQ, and correlations between the scales.

\begin{tabular}{|c|c|c|c|c|}
\hline Variables & $\begin{array}{l}\text { Overall Result } \\
(\mathrm{M} \pm \mathrm{SD})\end{array}$ & $\begin{array}{l}\text { Intrusion } \\
(\mathrm{M} \pm \mathrm{SD})\end{array}$ & $\begin{array}{c}\text { Hyperarousal } \\
(\mathrm{M} \pm \mathrm{SD})\end{array}$ & $\begin{array}{c}\text { Avoidance } \\
(\mathrm{M} \pm \mathrm{SD})\end{array}$ \\
\hline IES-R & $1.40 \pm .62$ & $1.02 \pm .72$ & $1.45 \pm .73$ & $1.79 \pm .82$ \\
\hline Variables & \multicolumn{2}{|c|}{$\begin{array}{c}\text { Sense of Security } \\
(\mathrm{M} \pm \mathrm{SD})\end{array}$} & \multicolumn{2}{|c|}{$\begin{array}{c}\text { Reflection on Security } \\
(\mathrm{M} \pm \mathrm{SD})\end{array}$} \\
\hline SEQ & \multicolumn{2}{|c|}{$3.68 \pm .68$} & \multicolumn{2}{|c|}{$4.08 \pm .57$} \\
\hline Variables & $\begin{array}{c}\text { IES-R } \\
\text { Overall Result } \\
\end{array}$ & $\begin{array}{c}\text { IES-R } \\
\text { Intrusion }\end{array}$ & $\begin{array}{c}\text { IES-R } \\
\text { Hyperarousal } \\
\end{array}$ & $\begin{array}{c}\text { IES-R } \\
\text { Avoidance }\end{array}$ \\
\hline SEQ Sense of Security & $\begin{array}{l}\mathrm{R}=-.25 \\
p<.0001\end{array}$ & $\begin{array}{l}\mathrm{R}=-.30 \\
p<.0001\end{array}$ & $\begin{array}{l}\mathrm{R}=-.30 \\
p<.0001\end{array}$ & $\begin{array}{l}\mathrm{R}=-.01 \\
p=.860\end{array}$ \\
\hline SEQ Reflection on Security & $\begin{array}{l}\mathrm{R}=.18 \\
p<.001\end{array}$ & $\begin{array}{l}\mathrm{R}=.20 \\
p<.0001\end{array}$ & $\begin{array}{l}\mathrm{R}=.18 \\
p<.0001\end{array}$ & $\begin{array}{l}\mathrm{R}=.07 \\
p=.204\end{array}$ \\
\hline
\end{tabular}

Abbreviations: M - mean; SD - standard deviation; IES-R - Impact of Event Scale - Revised; SEQ - Self Experiences Questionnaire; $\mathrm{R}$ - Spearman's correlation coefficient value; $p$ - statistical significance level.

Women scored significantly higher on the IES-R than men. Also, significantly higher values of the Intrusion, Hyperarousal, and Avoidance subscales were observed in women compared to men $p<.0001$ (Figure 2). Men had a significantly higher Sense of Security than women $(3.84$ vs. $3.64, p<.01)$. 


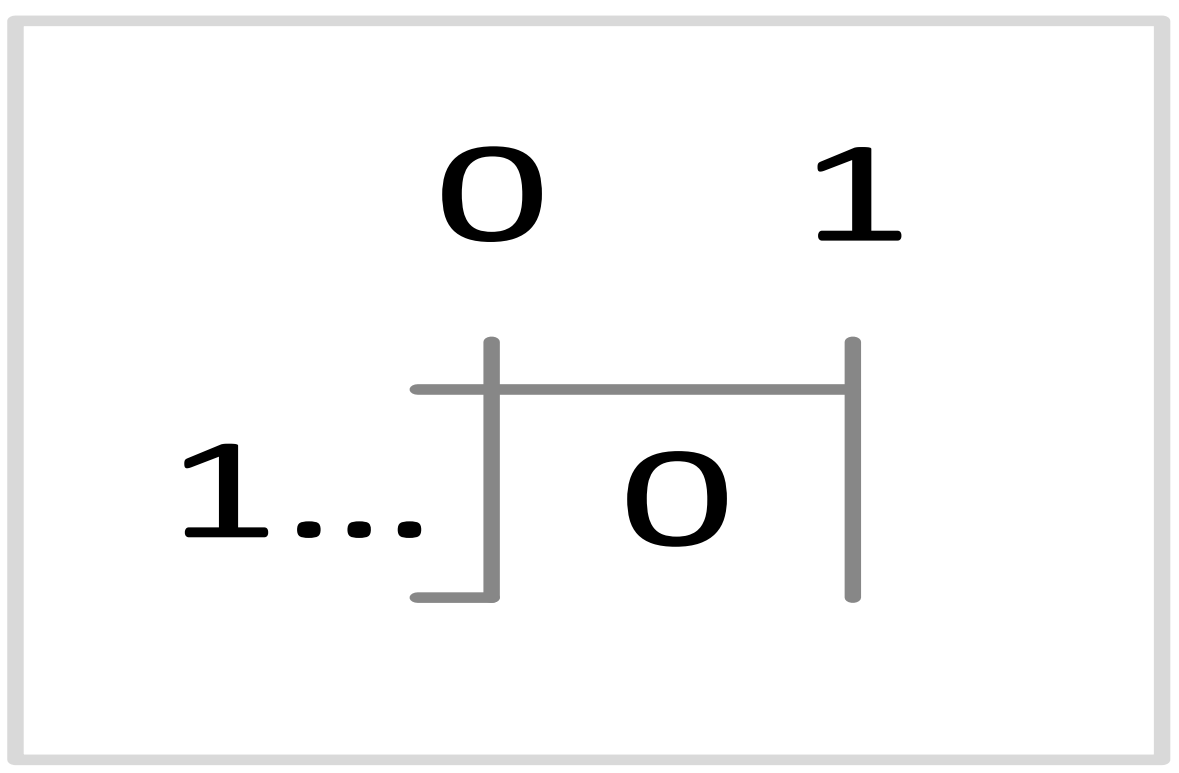

Figure 2: Student PTSD traumatic stress scores by gender.

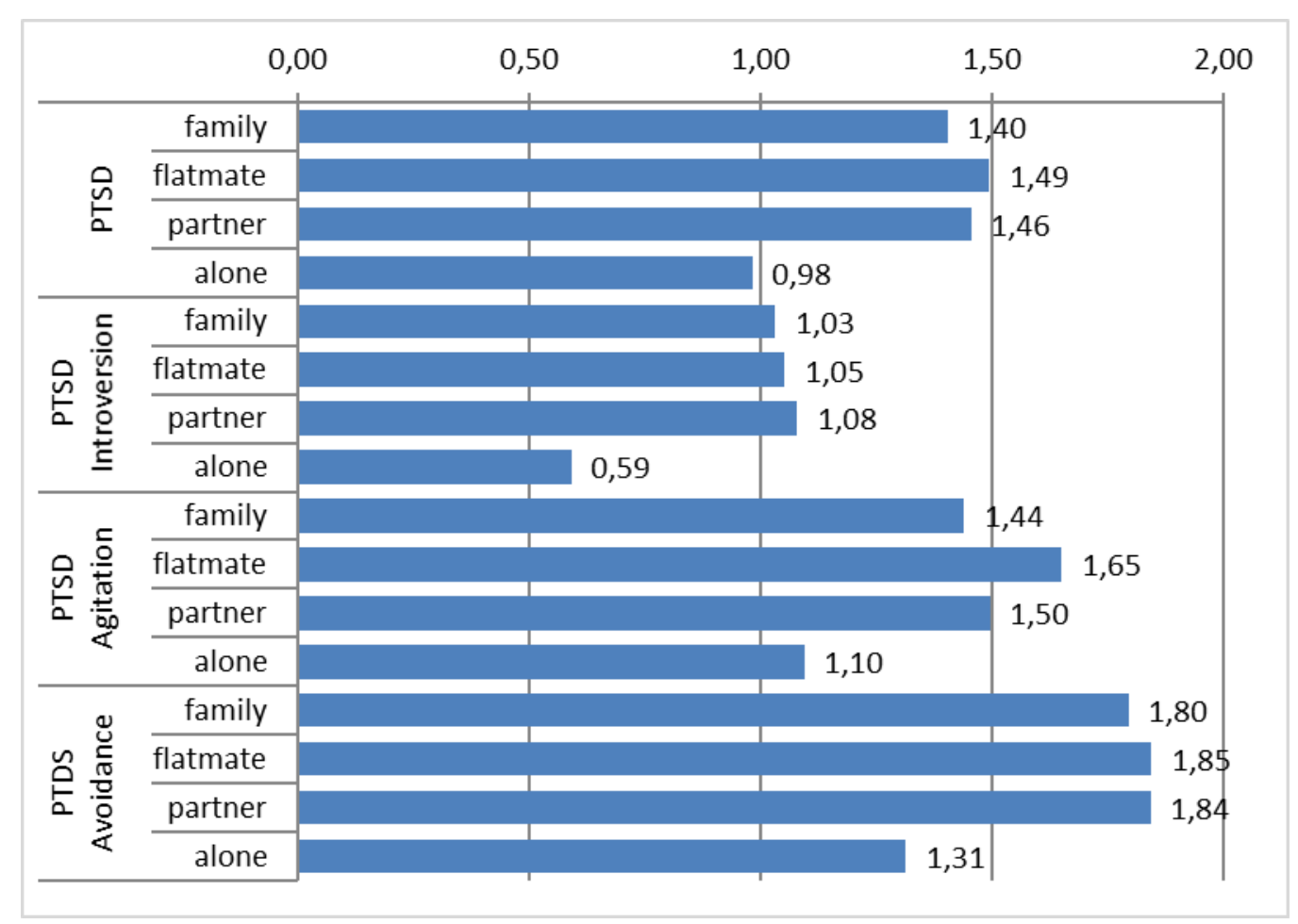

Figure. 3. PTSD traumatic stress scores among students by type of residence

Respondents living alone had considerably lower IES-R PTSD values than respondents living with others $(p<.05)$. Similar relationships were associated with the values for Intrusion, Hyperarousal, and Avoidance, but the differences were not statistically 
significant $(p>.05)$ (Figure 3). Age and place of residence were not related to the severity of PTSD traumatic stress symptoms among students according to the IES-R $(p>.05)$.

Field of study, type of education, and year of the study did not differentiate the severity of IES-R traumatic stress and experience of security among students according to the SEQ $(p>.05)$ (Figure 3).

\subsection{Students' perceptions of remote learning during the COVID-19 pandemic}

Tables 3 and 4 present the perception of remote learning during the lockdown due to the COVID-19 epidemic in the opinion of students, and their relationship with selected variables. The results obtained indicate that with respondents' age, "Concern about experiencing technical problems during exams or thesis defense" decreased significantly $(\mathrm{R}=$ -.13, $\mathrm{p}<$.009), as did "Fear of insufficient acquisition of practical knowledge, affecting professional future." $(\mathrm{R}=-.15, \mathrm{p}<.004)$, and concerns for "Quality of family life in the financial context" $(\mathrm{R}=-.15, \mathrm{p}<.004)$, "Amount of time spent on developing interests and hobbies" $(\mathrm{R}=-.11, \mathrm{p}<.029)$, and "Quality of family relationships" $(\mathrm{R}=-.11, \mathrm{p}<.04)$.

As the severity of PTSD increased, the severity of all analyzed fears present in the respondents (variables 10 to 15 in Table 3) and the quality of peer relationships increased significantly.

Significantly greater feelings of security were associated with respondents who experienced timelier delivery of information (to students) about exam deadlines ( $R=.12, \mathrm{p}<$ .025), also with respondents who perceived improved quality of family life in the financial context $(\mathrm{R}=.22, \mathrm{p}<.0001)$, more time devoted to pursuing interests $(\mathrm{R}=.20, \mathrm{p}<.0001)$, or higher quality peer $(\mathrm{R}=.16, \mathrm{p}<.002)$ and family relationships $(\mathrm{R}=.24, \mathrm{p}<.0001)$. Fear of missing a semester was significantly lower than sense of security $(R=-.24, p<.0001)$.

A significantly higher level of security in reflection was accompanied by students with a greater level of material completed in the remote education system $(R=.12, p<.025)$ and a greater fear of insufficient acquisition of practical knowledge, affecting their professional future $(\mathrm{R}=.14, \mathrm{p}<.006)$, while a significantly lower level of security in reflection was accompanied by students perceiving a lower degree of timeliness in being provided with information about course deadlines $(\mathrm{R}=-.13, \mathrm{p}<.013)$.

The time devoted to the implementation of curriculum in the on-line system significantly increased for non-medical rather than medical students $(3.13$ vs. $2.68, \mathrm{p}<.008)$. The severity of concerns related to various factors of remote learning was significantly stronger among females, and the selected factor of apprehension of remote learning during the lockdown period was expressed more frequently by non-medical majors. 
Table 3. Student perceptions of the remote learning situation during the lockdown period of the COVID-19 epidemic, and selected variables

\begin{tabular}{|c|c|c|c|c|c|c|c|c|c|}
\hline \multirow[t]{2}{*}{ Nr. } & \multirow[t]{2}{*}{ Variables } & \multicolumn{2}{|c|}{ Age } & \multicolumn{2}{|c|}{ IES-R } & \multicolumn{2}{|c|}{$\begin{array}{c}\text { Sense of security } \\
\text { SEQ }\end{array}$} & \multicolumn{2}{|c|}{$\begin{array}{c}\text { Reflection on Security } \\
\text { SEQ }\end{array}$} \\
\hline & & $\mathrm{R}$ & $p$ & $\mathrm{R}$ & $p$ & $\mathrm{R}$ & $p$ & $\mathrm{R}$ & $p$ \\
\hline 1. & $\begin{array}{l}\text { Time spent on } \\
\text { implementation of } \\
\text { curriculum in the } \\
\text { online system (classes } \\
\text { and related tasks) }\end{array}$ & .05 & .310 & .02 & .659 & -.10 & .067 & -.01 & .858 \\
\hline 2. & $\begin{array}{l}\text { Effectiveness and } \\
\text { quality of distance } \\
\text { learning activities }\end{array}$ & .06 & .264 & -.08 & .148 & -.04 & .448 & -.07 & .211 \\
\hline 3. & $\begin{array}{l}\text { Actual number of } \\
\text { classes held }\end{array}$ & -.05 & .326 & .04 & .403 & -.09 & .096 & -.10 & .054 \\
\hline 4. & $\begin{array}{l}\text { Level and degree of } \\
\text { completion of the } \\
\text { material in the distance } \\
\text { education system }\end{array}$ & .10 & .065 & .09 & .070 & .00 & .994 & .12 & .025 \\
\hline 5. & $\begin{array}{l}\text { Motivation to engage in } \\
\text { online learning }\end{array}$ & .10 & .067 & -.08 & .113 & .07 & .177 & -.02 & .715 \\
\hline 6. & $\begin{array}{l}\text { Availability } \\
\text { academic teachers in } \\
\text { the online system for } \\
\text { conducting classes }\end{array}$ & -.06 & .283 & -.04 & .430 & -.03 & .600 & -.05 & .302 \\
\hline 7. & $\begin{array}{l}\text { Promptness in } \\
\text { providing students } \\
\text { with information on } \\
\text { appointed times for } \\
\text { holding classes }\end{array}$ & -.01 & .774 & -.08 & .124 & .03 & .596 & -.13 & .013 \\
\hline 8. & $\begin{array}{l}\text { Promptness in } \\
\text { providing students } \\
\text { with information on } \\
\text { deadlines for credits } \\
\text { and exams }\end{array}$ & -.05 & .361 & -.09 & .073 & .12 & .025 & -.01 & .778 \\
\hline 9. & $\begin{array}{l}\text { Fairness in assessment } \\
\text { of credits and exams in } \\
\text { the online format }\end{array}$ & .08 & .130 & -.03 & .595 & .08 & .106 & .04 & .464 \\
\hline 10. & $\begin{array}{lr}\text { Concern } & \text { about } \\
\text { technical } & \text { problems } \\
\text { during exams or thesis } \\
\text { defenses }\end{array}$ & -.13 & .009 & .13 & .011 & -.08 & .107 & .10 & .063 \\
\hline 11. & $\begin{array}{l}\text { Concern about not } \\
\text { passing the semester }\end{array}$ & -.02 & .707 & .25 & .000 & -.24 & .000 & .03 & .605 \\
\hline 12. & $\begin{array}{l}\text { Fear of not completing } \\
\text { the practical training } \\
\text { (practical classes and } \\
\text { internships) in the } \\
\text { semester }\end{array}$ & -.03 & .579 & .19 & .001 & -.10 & .077 & .09 & .097 \\
\hline 13. & $\begin{array}{l}\text { Fear of insufficient } \\
\text { acquisition of practical } \\
\text { knowledge, influencing }\end{array}$ & -.15 & .004 & .23 & .000 & -.08 & .135 & .14 & .006 \\
\hline
\end{tabular}




\begin{tabular}{|c|c|c|c|c|c|c|c|c|c|}
\hline & professional future & & & & & & & & \\
\hline 14. & $\begin{array}{l}\text { Concern about } \\
\text { extending the academic } \\
\text { year }\end{array}$ & -.06 & .212 & .14 & .007 & .04 & .422 & .05 & .359 \\
\hline 15. & $\begin{array}{l}\text { Fear of difficulties in } \\
\text { obtaining a job in the } \\
\text { (learned) profession }\end{array}$ & .01 & .886 & .15 & .003 & -.07 & .153 & .09 & .098 \\
\hline 16. & $\begin{array}{l}\text { Quality of family life in } \\
\text { the financial context }\end{array}$ & -.15 & .004 & -.14 & .008 & .22 & .000 & -.05 & .326 \\
\hline 17. & $\begin{array}{l}\text { Amount of time } \\
\text { devoted to hobbies and } \\
\text { interests }\end{array}$ & -.11 & .029 & -.07 & .209 & .20 & .000 & .03 & .616 \\
\hline 18. & $\begin{array}{l}\text { Quality of peer } \\
\text { relationships }\end{array}$ & -.04 & .440 & -.15 & .005 & .16 & .002 & -.02 & .769 \\
\hline 19. & $\begin{array}{l}\text { Quality of family } \\
\text { relationships }\end{array}$ & -.11 & .041 & -.02 & .660 & .24 & .000 & .05 & .338 \\
\hline
\end{tabular}

Abbreviations: IES-R - Impact of Event Scale - Revised; SEQ - Self Experiences Questionnaire; $\mathrm{r}$ - Spearman's correlation coefficient value; $\mathrm{p}$ - statistical significance level.

Table 4. Perceptions of the remote learning situation during the lock-down period of the COVID-19 epidemic (March 11-June 8, 2020) as perceived by students, and selected variables: gender and type of study

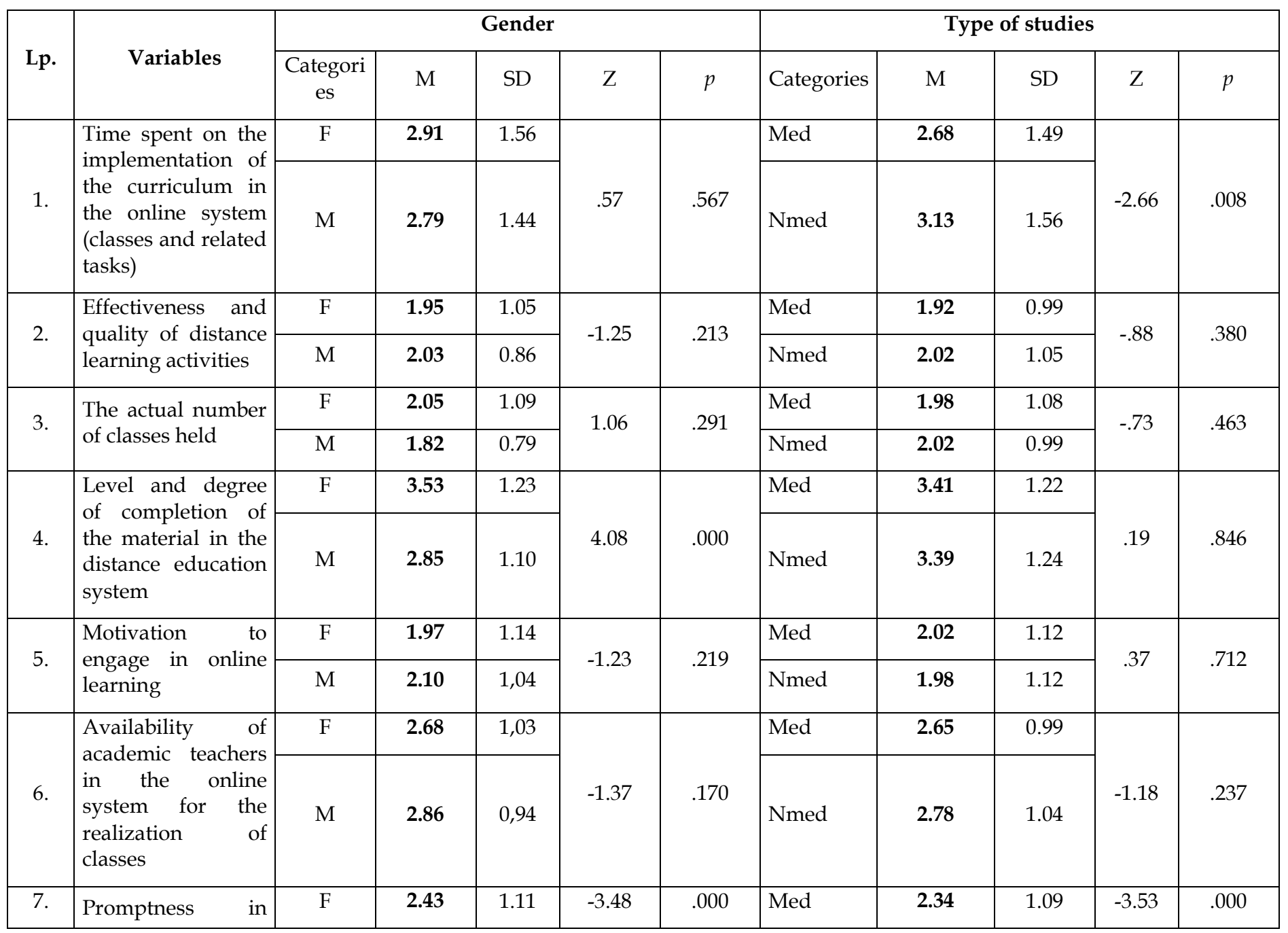




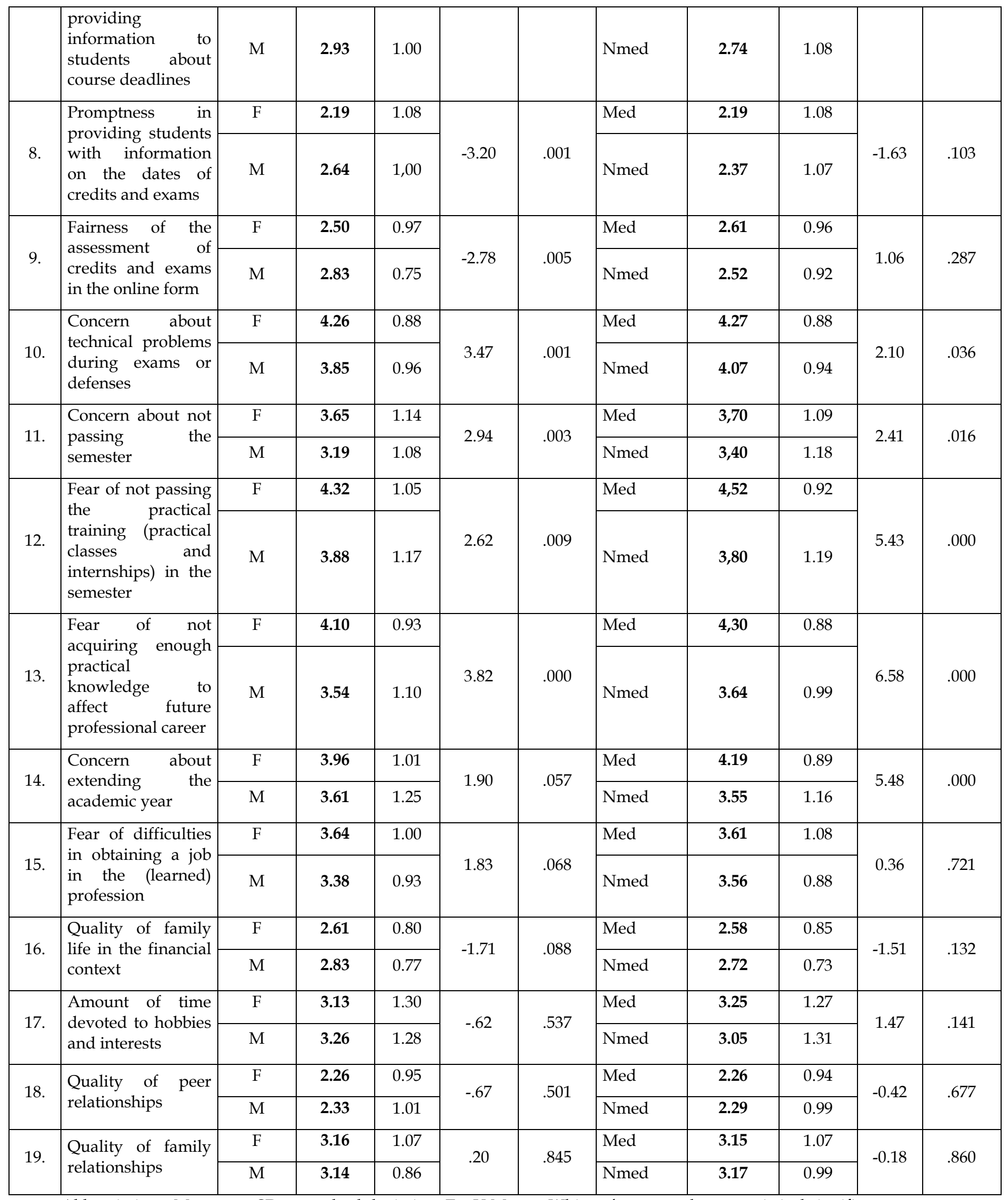

Abbreviations: M - mean; SD - standard deviation; Z - U Manna-Whitney's test result; p - statistical significance level; F - female; M - male; Med. - medical major; Nmed - non-medical major. 


\section{Discussion}

The COVID-19 outbreak poses a huge challenge to the national education system, health care, and the country's economy, while the virus itself poses a threat to physical as well as mental health. For these reasons, the COVID-19 pandemic will have long-term consequences, affecting international and national public health policy (Forte, Favieri, Tambelli, et al., 2020b). The COVID-19 pandemic quickly led to the closure of universities and colleges around the world, along with government recommendations to observe social distancing to help flatten the infection curve and reduce deaths from the disease. The most important safeguard against the pandemic, known as "social distancing" or "physical distancing" was the limiting of interpersonal contact, thus minimizing the kind of social transmission able to quickly develop in dense social networks including but not limited to university campuses (Weeden \& Benjamin, 2020). The impact of the pandemic on higher education was dramatic and transformational, and a common trend in education systems around the world as well as in Poland was to respond to the pandemic with "emergency elearning" protocols, meaning a rapid shift from the classroom to online learning systems. The sudden change in adapting and implementing online learning led to overwork and stress involving all participants in the changing system, including students, who were very much affected (Rashid \& Yadav, 2020)

Our study was conducted during the first wave of experiences in the changing system in higher education associated with the COVID-19 epidemic. We expected that the severity of PSTD traumatic stress symptoms would be high, but the results show that they were not severe in the group studied (the IES-R for the research group was $1.40 \pm .62$ ). The factors significantly influencing the occurrence of traumatic stress symptoms were female gender and living alone.

The symptoms of post-traumatic stress disorder appear after traumatic events beyond the scope of normal human experience, for example: violent physical assault, torture, accidents, rape, or natural disasters (Deja, Denke, Weber-Carstens, et al., 2006). The nonexacerbated intensity of traumatic stress symptoms in the general population during the COVID-19 pandemic is supported by the findings of Forte. Forte, Favieri, Tambelli, et al. (2020a) conducted among Italians, in which the overall mean score of the IES-R scale was 22.38, while the Intrusion subscale was 1.01, Avoidance subscale was 1.06, and the Hyperarousal subscale was .98. Meanwhile, in the general population of Egypt, the following mean scores were obtained: overall score 34.25, Intrusion - 13.68, Avoidance - 12.83, and in the Hyperarousal subscale - 7.73 (El-Zoghby, Soltan, Salama, et al., 2020). A similar mean score indicating mild stressful effects of the pandemic was found in the Chinese population in research by Zhang and Ma (2020) and Wang, Pan, Wan, et al. (2020). A study by Li, Fu, Fan, et al. (2021) found that the prevalence of PTSD among university and college students in 
Wuhan four months after the COVID-19 pandemic was 16.3\%. A study of university students from Chengdu Province and Chongqing City from January 30 to February 8, 2020, showed the prevalence of post-traumatic stress disorder and depression were $2.7 \%$ and $9.0 \%$, respectively, one month after the COVID-19 outbreak there (Tang, $\mathrm{Hu}, \mathrm{Hu}$, et al., 2020).

Based on analysis conducted by Almaiah, Khasawneh, Althunibat (2020), referring to the critical challenges and factors affecting the e-learning system during the COVID-19 pandemic, the authors conclude that in order to accept the e-learning system, universities must consider the following categories: 1) technological factors, 2) e-learning system quality factors, 3) cultural aspects, 4) self-efficacy factors, and 5) confidence factors. Distance learning is neither simple nor inexpensive. It takes considerable effort and resources. Ensuring good quality education requires both ongoing monitoring of the learning process and, parallel to the didactic process, a continuous process of modification and improvement of teaching tools for tomorrow. The very rapid transition from traditional to remote education during the COVID-19 outbreak has created many difficulties for both students and teachers. The students in our study expressed many concerns about the technical problems of online contact, limitations for full realization of learning outcomes, and fears of not passing the semester or of having extended work in the semester. These fearsas well as concerns about the quality of their peer relationships grew alongside intensification of PSTD traumatic stress symptoms.

In a study of 830 students participating in distance learning programs who responded to an online survey (26 questions), it was found that while students were generally positive about their distance learning experience; they faced challenges to their education, especially in relation to effective teaching practices and communication patterns (Markova, Glazkova, Zaborova, 2017). A study of Romanian students ( $n=762)$ during the coronavirus pandemic indicated a hierarchy of problems arising from remote learning related to technical issues including instructors' lack of technical skills, teaching styles inappropriately adapted to the online environment, and lack of interaction in the teaching process (Coman, Tîru, MesesanSchmitz, et al., 2020).

With every crisis come profound challenges and opportunities for transformation. Past educational crises have shown that it is possible to build better and to achieve better results. The contemporary experience of rapid changes in the university remote education system are undoubtedly forming a new standard of academic education.

\section{Conclusions}

Preliminary results of our research, conducted on a group of students at a time of accelerated transformation from traditional education to a remote system and during a time of intense psychological pressure related to the COVID-19 epidemic in its first phase of 
development, indicate that symptoms of traumatic stress in the studied group did not increase. Increased symptoms did occur in the Avoidance subscale, which is associated with a significant effort to rid oneself of thoughts, emotions, or conversations related to the trauma experienced. Students' experience of security was maintained at optimal levels and indicated a preserved sense of security. It was observed that students with higher severity of traumatic stress symptoms exhibited lesser feelings of security and showed significantly more anxiety about many factors related to distance learning. Concerns about the quality of remote education were significantly more common among female and non-medical students.

\section{Bibliography:}

Almaiah, M. A., Al-Khasawneh, A., Althunibat, A. (2020). Exploring the critical challenges and factors influencing the E-learning system usage during COVID-19 pandemic, Education and Information Technologies, 25, 5261-5280, https:/ / doi.org/10.1007/s10639020-10219-y.

Bonanno, G.A., Ho, S.M., Chan, J.C., Kwong, R.S., Cheung, C.K., Wong, C.P., Wong, V.C. (2008). Psychological resilience and dysfunction among hospitalized survivors of the SARS epidemic in Hong Kong: a latent class approach, Health Psychology, 27, 659-667, https://doi.org/10.1037/0278-6133.27.5.659.

Bozkurt, A., \& Sharma, R. (2020). Emergency remote teaching in a time of global crisis due to Coronavirus pandemic, Asian Journal of Distance Education, 15, 1-6, https://doi.org/10.1007/s10639-021-10520-4.

Coman, C., Tîru, L. G., Mesesan-Schmitz, L., Stanciu, C., Bularca, M. C. (2020). Online teaching and learning in higher education during the coronavirus pandemic: students' perspective. Sustainability, 12, 10367, https://doi.org/10.3390/su122410367.

Deja, M., Denke, C., Weber-Carstens, S., Schröder, J., Pille, C. E., Hokema, F., Falke, K. J., Kaisers, U. (2006). Social support during intensive care unit stay might improve mental impairment and consequently health-related quality of life in survivors of severe acute respiratory distress syndrome, Critical Care, 10, R147, https://doi.org/10.1186/cc5070.

El-Zoghby, S. M., Soltan, E. M., Salama, H. M. (2020). Impact of the COVID-19 pandemic on mental health and social support among adult Egyptians, Journal of Community Health, 45, 689-695, https:/ / doi.org/10.1007/s10900-020-00853-5.

Forte, G., Favieri, F., Tambelli, R., Casagrande, M. (2020a). COVID-19 pandemic in the Italian population: validation of a Post-Traumatic Stress Disorder Questionnaire and prevalence of PTSD symptomatology, International Journal of Environmental Research and Public Health, 17, 4151, https://doi.org/10.3390/ijerph17114151. 
Forte, G., Favieri, F., Tambelli, R., Casagrande, M. (2020b). The enemy which sealed the world: effects of COVID-19 diffusion on the psychological state of the Italian population, Journal of Clinical Medicine, 9, 1802, https://doi.org/10.3390/jcm9061802.

González Ramírez, L. P., Martínez Arriaga, R. J., Hernández-Gonzalez, M. A., De la RocaChiapas, J. M. (2020). Psychological distress and signs of post-traumatic stress in response to the COVID-19 health emergency in a mexican sample. Psychology Research and Behavior Management, 13, 589-597, https:/ / doi.org/10.2147/PRBM.S259563.

Guadix, S.W., Winston, G.M., Chae, J.K., Haghdel, A., Chen, J., Younus, I., Radwanski, R., Greenfield, J.P., Pannullo, S.C. (2020). Medical student concerns relating to neurosurgery education during COVID-19, World Neurosurgery, 139, e836-e847, https://doi.org/10.1016/j.wneu.2020.05.090.

Holmes, E.A., O'Connor, R.C., Hugh, P., Irene, T., Simon, W., Louise, A., Clive, B., Helen, C., Roxane, C.S., Ian, E., et al. (2020). Multidisciplinary research priorities for the COVID19 pandemic: A call for action for mental health science, The Lancet Psychiatry, 7, 547560, https:/ / doi.org/10.1016/S2215-0366(20)30168-1.

Huang, C.L., Wang, Y.M., Li, X.W., Ren, L.L., Zhao, J.P., Hu, Y., Zhang, L., Fan, G., Xu, G., $\mathrm{Gu}$, X.; et al. (2020). Clinical features of patients infected with 2019 novel coronavirus in Wuhan, China, The Lancet, 10223, 497-506, https://doi.org/10.1016/S01406736(20)30183-5.

Jakovljevic, M., Bjedov, S., Jaksic, N., Jakovljevic, I. (2020). COVID-19 pandemia and public and global mental health from the perspective of global health security, Psychiatria Danubina, 32, 6-14, https://doi.org/10.24869/psyd.2020.6.

James, R. K., Gilliland, B. E. (2006). Strategie interwencji kryzysowej. [Crisis intervention strategies]. Warsaw: PARPAMEDIA, Wydawnictwo Edukacyjne.

Juczyński, Z., Ogińska-Bulik, N. (2009). Pomiar zaburzeń po stresie traumatycznym - polska wersja Zrewidowanej skali Wpływu Zdarzeń. [Measurement of post-traumatic stress disorder - Polish version of Impact Event Scale-Revised], Psychiatria, 6, 15-25.

Klamut, R. (2019). Dwuczynnikowy model doświadczania bezpieczeństwa - założenia teoretyczne i empiryczna weryfikacja: Kwestionariusz Doświadczania Bezpieczeństwa (KDB). [Two-factor model of safety experience - theoretical assumptions and empirical verification: Safety Experience Questionnaire], Polskie Forum Psychologiczne, 24, 308-323.

Keita, M. M., Taverne, B., Sy Savané, S., March, L., Doukoure, M., Sow, M. S., Touré, A., Etard, J. F., Barry, M., Delaporte, E., PostEboGui Study Group (2017). Depressive symptoms among survivors of Ebola virus disease in Conakry (Guinea): preliminary results of the PostEboGui cohort, BMC Psychiatry, 17, 127, https:// doi.org/10.1186/s12888-017-1280-8. 
Lau, J.T.F., Yang, X., Pang, E., Tsui, H.Y., Wong, E., Yun, K.W. (2005). SARS-related perceptions in Hong Kong, Emerging Infectious Diseases, 11, 417-424, https://doi.org/10.3201/eid1103.040675.

Li, X., Fu, P., Fan, Ch., Zhu, M., Li, M. (2021). COVID-19 stress and mental health of students in locked-down colleges, International Journal of Environmental Research and Public Health, 18, 771, https:// doi.org/10.3390/ijerph18020771.

Markova, T., Glazkova, I., Zaborova, E. (2017). Quality issues of online distance learning, Procedia - Social and Behavioral Sciences, 237, 685-691, https://doi.org/10.1016/j.sbspro.2017.02.043.

Markham, A., Buchanan, E. (2012). Ethical decision-making and Internet research: Recommendations from the AOIR Ethics Working Committee (Version 2.0). Retrieved April 1, from: http://www.aoir.org/reports/ethics.pdf .

Mian, A., \& Khan, S. (2020). Medical education during pandemics: a UK perspective, BMC Medicine, 18, 100, https:/ / doi.org/10.1186/s12916-020-01577-y.

Pfefferbaum, B., \& North, C.S. (2020). Mental health and the COVID-19 pandemic, The New England Journal of Medicine, 383, 510-512, https:// doi.org/10.1056/NEJMp2008017.

Poleszak, W. (2020). Psychologiczna sytuacja dzieci i młodzieży w dobie epidemii. [Psychological situation of children and adolescents in the epidemic], (in:) J. Pyżalski (ed.), Edukacja w czasach pandemii wirusa COVID-19. Z dystansem o tym, co robimy obecnie jako nauczyciele [Education in times of the COVID-19 pandemic. Keep in mind what we are doing today as teachers], 7-15, Warsaw: EduAkcja.

Rashid, S., \& Yadav, S. S. (2020). Impact of Covid -19 pandemic on higher education and research, Indian Journal of Human Development, 23, 340-343, https://doi.org/10.1177/0973703020946700.

Rossi, R., Socci, V., Talevi, D., Mensi, S., Niolu, C., Pacitti, F., Di Marco, A., Rossi, A., Siracusano, A., Di Lorenzo, G. (2020). COVID-19 pandemic and lockdown measures impact on mental health among the general population in Italy, Frontiers in Psychiatry, 11, 790, https:/ / doi.org/10.3389/fpsyt.2020.00790.

Shalev, A., Liberzon, I., Marmar, C. (2017). Post-traumatic stress disorder, The New England Journal of Medicine, 376, 2459-2469, https:/ / doi.org/10.1056/NEJMra1612499.

Shi, L., Lu, Z. A., Que, J.Y., Huang, X. L., Liu, L., Ran, M. S., Gong, Y. M., Yuan, K., Yan, W., Sun, Y. K., et al. (2020). Prevalence of and risk factors associated with mental health symptoms among the general population in China during the coronavirus disease 2019 pandemic, JAMA Network Open, 3, e2014053, https://doi.org/10.1001/jamanetworkopen.2020.14053.

Sim M. (2016). Psychological trauma of Middle East Respiratory Syndrome victims and bereaved families, Epidemiology and Health, 38, e2016054, https://doi.org/10.4178/epih.e2016054. 
Sprang, G., \& Silman, M. (2013). Posttraumatic stress disorder in parents and youth after health-related disasters, Disaster Medicine and Public Health Preparedness, 7, 105-110, https://doi.org/10.1017/dmp.2013.22.

Sun, S., Goldberg, S. B., Lin, D., Qiao, S., Operario, D. (2021). Psychiatric symptoms, risk, and protective factors among university students in quarantine during the COVID-19 pandemic in China, Globalization and Health, 17, 15, https://doi.org/10.1186/s12992021-00663-x.

Tang, W., Hu, T., Hu, B., Jin, C., Wang, G., Xie, C., Chen, S., Xu, J. (2020). Prevalence and correlates of PTSD and depressive symptoms one month after the outbreak of the COVID-19 epidemic in a sample of home-quarantined Chinese university students, Journal of Affective Disorders, 274, 1-7, https:// doi.org/10.1016/j.jad.2020.05.009.

Terhakopian, A., \& Benedek, D. M. (2007). Hospital disaster preparedness: mental and behavioral health interventions for infectious disease outbreaks and bioterrorism incidents, American Journal of Disaster Medicine, 2, 43-50.

Wang, C., Pan, R., Wan, X., Tan, Y., Xu, L., Ho, C.S., Ho, R.C. (2020). Immediate psychological responses and associated factors during the initial stage of the 2019 coronavirus disease (COVID-19) epidemic among the general population in China, International Journal of Environmental Research and Public Health, 17, 1729, https://doi.org/10.3390/ijerph17051729.

Wei, Y., Meng, X.D., Ni, Y.X. (2020). The investigation of anxiety and PTSD of populations in community and factors analysis during the pandemic of COVID-19, Practice Journal of Clinical Medicine, 17, 267-270.

Weiss, D., \& Marmar, C. (1997). The Impact of Event Scale-Revised. In J. Wilson, \& T. Keane, (Eds.), Assessing psychological trauma and PTSD: a handbook for practitioners, (pp. 399-411). New York: Guildford Press.

Weeden, K. A., \& Benjamin, C. (2020). The small-world network of college classes: implications for epidemic spread on a university campus, Sociological Science, 7, 222241.

WHO, (2020). Statement on the second meeting of the International Health Regulations (2005) Emergency Committee regarding the outbreak of novel coronavirus (2019- $n$ CoV). Retrieved April 1, 2021, from: https://www.who.int/news-room/detail/30-01-2020-statementon-thesecond-meeting-of-the-international-health-regulations-(2005)-emergencycommittee-regarding-the-outbreak-of-novel-coronavirus-(2019-ncov).

Xu, J., Zheng, Y., Wang, M., Zhao, J., Zhan, Q., Fu, M., Wang, Q., Xiao, J., Cheng, Y. (2011). Predictors of symptoms of posttraumatic stress in Chinese university students during the 2009 H1N1 influenza pandemic, Medical Science Monitor, 17, PH60-PH64, https://doi.org/10.12659/msm.881836. 
Yuan, K., Gong, Y.M., Liu, L., Sun, Y.K., Tian, S.S., Wang, Y.J., Zhong, Y., Zhang, A. ., Su, S.Z., Liu, X.X., Zhang, Y.X., et al. (2021). Prevalence of posttraumatic stress disorder after infectious disease pandemics in the twenty-first century, including Covid-19: a meta-analysis and systematic review, Molecular Psychiatry, 1-17, https:/ / doi.org/10.1038/s41380-021-01036-x.

Zhang, Y., \& Ma, Z.F. (2020). Impact of the COVID-19 pandemic on mental health and quality of life among local residents in Liaoning Province, China: a cross-sectional study, International Journal of Environmental Research and Public Health, 17, 2381, https://doi.org/10.3390/ijerph17072381. 